\title{
The effect on river and earth dam caused by large height mining in underground coal mine - a case in Inner Mongolia
}

\author{
Jianghua $\mathrm{Li}^{1,2, *}$, Ling $\mathrm{Li}^{1,2}$, and Hui $\mathrm{Xu}^{1,2}$ \\ ${ }^{1}$ Mine Safety Technology Branch of China Coal Research Institute, Beijing 100013, China \\ ${ }^{2}$ State Key Laboratory of Coal Mining and Clean Utilization, China Coal Research Institute, Beijing 100013, China
}

\begin{abstract}
Some coal seams located in the shallow area belong to Jurassic system strata in Inner Mongolia, China. There may be some effect on the rivers and earth dam on the earth surface of coal field after large height mining. Hydraulic connection was analyzed according to the hydrogeological condition and additional exploration results in Wotugou coal mine. Empirical formulas were used to predict overburden failure height after analyzing the strength type of overlying rocks. The deformation of earth dam was predicted through probability integral method under large height mining. The final research results include: (1) Quaternary system aquifer belongs to the type of weak to strong watery property and has an intimate hydraulic connection with the Youfang River. (2) The overlying rocks of 2-2 coal seam belong to medium hard type for the average uniaxial compressive strength of $25.52 \mathrm{MPa}$. The maximum height of fissure zone is $92.40 \mathrm{~m}$, there was no effect on Youfang River after large height mining under the depth of $251.46 \mathrm{~m}$. (3) The maximum surface subsidence reached $1.7 \mathrm{~m}$ and the horizontal deformation reached the allowable maximum value $4.0 \mathrm{~mm} / \mathrm{m}$, there would be some effect on the earth dam, so some safety measures were put forward and needed to be done.
\end{abstract}

\section{Introduction}

Coal distributes widely, but the hydrogeological condition is very complex in China. Many coal mines are threatened by different aquifers and surface water bodies ${ }^{[1,2]} .1950 \mathrm{~s}$, a great deal of experimental investigations about the mining under water bodies were carried out. Experimental study and production practice indicated coal was mined safely under rivers, lakes, seas and different aquifers ${ }^{[3,4]}$. However, in 1980s, large mining height and fullmechanized caving mining methods were used widely with the development of the level of mechanization. Then the mine pressure appeared acutely and the extent of overburden failure brought new problems caused by the advanced technology ${ }^{[5-7]}$. In the 21 st century, with the development of large mining height method and computer technology, the characteristics of caving zone and fissure zone have been known specifically under High-strength underground mining. The empirical formulas of caving zone and fissure zone heights have also been formed and scientifically instructed the safety mining under water bodies $^{[8-10]}$.

Taking Wotugou coal mine as an example, hydraulic connection was researched through analyzing the hydrogeological condition and additional exploration results. Empirical formulas were used to predict overburden failure height after analyzing the strength type of overlying rocks and the effect on the Youfang River was evaluated under large height mining. The deformation of earth dam was predicted through probability integral method and under the effect on the earth dam was evaluated under high strength mining, then some safety measures were put forward.

\section{General situation of research area}

\subsection{Mining status}

Wotugou coal mine has the production scale of $0.9 \mathrm{Mt} / \mathrm{a}$, and excavates from $+850 \mathrm{~m}$ to $+1070 \mathrm{~m}$ (above sea level) in Inner Mongolia. The mine excavates 2-2 coal seam of first panel, with the thickness of $3.47 \mathrm{~m}$ to $4.12 \mathrm{~m}$, and average thickness is $3.84 \mathrm{~m}$. The average depth of $2-2$ coal seam is $251.46 \mathrm{~m}$ and the average dip angle is $1.5^{\circ}$, which belongs to nearly flat seam. The mining method of strike long-wall comprehensive mechanization of a full mining height and the management of all caving the roof are used. Neighborhood coal mines are shown in Fig. 1.

\footnotetext{
*Corresponding author: Jianghua_Lee@163.com
} 


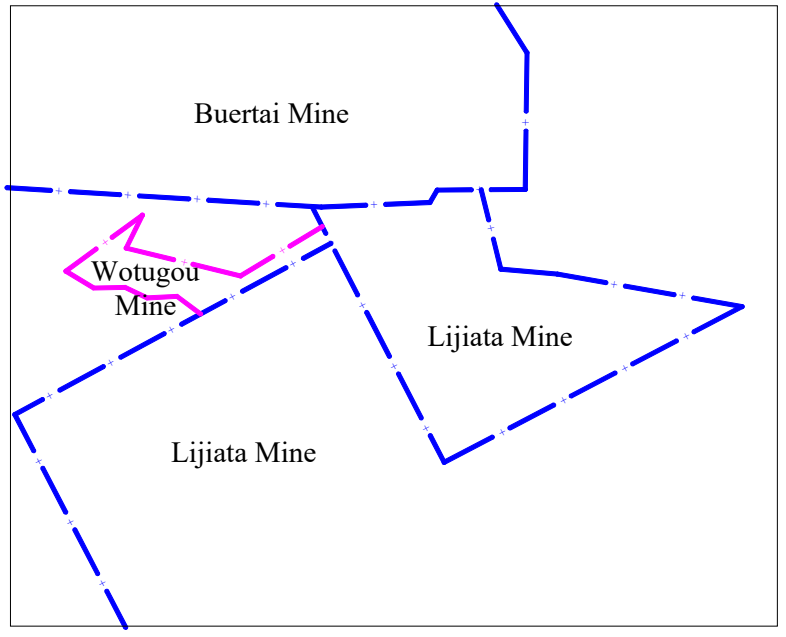

Fig. 1. Neighborhood coal mines of Wotugou mine

The terrain in this area is badly cut. Youfang River is a north-south ravine on the surface of mining area and the flow direction is from south to north. An earth dam with the top width of $5.0 \mathrm{~m}$, bottom width of $20.0 \mathrm{~m}$ and height of $3 \sim 6 \mathrm{~m}$ was constructed on the river. There are two ponds in the north and south of earth dam (as shown in Fig. 1). The mining faces near the Youfang River are shown in Fig. 2, the reality images of river and earth dam are shown in Fig. 3.

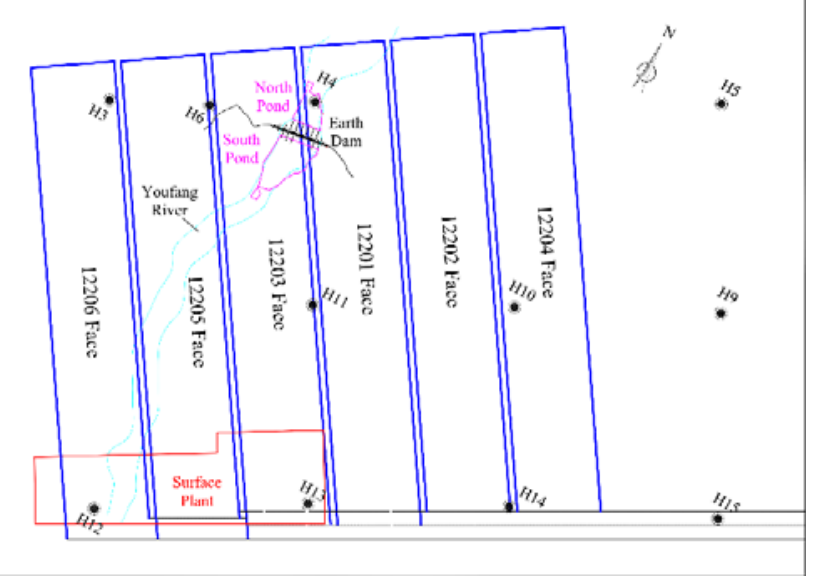

Fig. 2. The mining faces near Youfang River

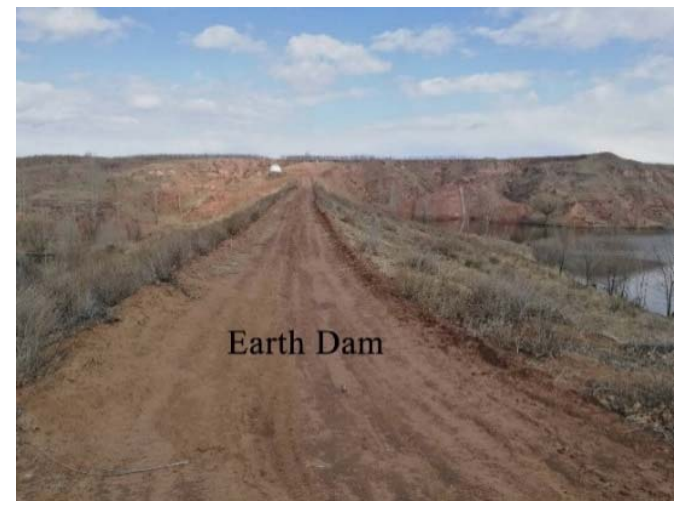

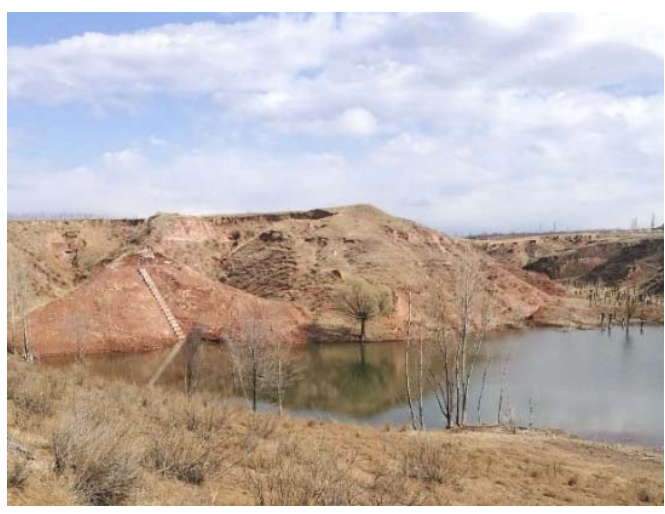

Fig. 3. Reality images of river and earth dam

\subsection{Hydrogeological condition}

According to the hydrogeological condition and additional exploration results, the hydraulic connection of aquifers are as follows:

\section{(1) Quaternary system aquifer}

The unit flow rate of water-bearing strata is 0.09-1.29 $\mathrm{L} /(\mathrm{m} . \mathrm{s})$ and the permeability coefficient is $16.54-90.27$ $\mathrm{m} / \mathrm{d}$ of pore phreatic aquifer in Quaternary system strata, so it belongs to the type of weak to strong watery property. The thickness of aquifer is usually less than $10 \mathrm{~m}$, and the permeability performance is strong. Phreatic aquifer has very close hydraulic connections with atmospheric precipitation and surface water body.

\section{(2) Cretaceous system aquifer}

The unit flow rate of water-bearing strata is $0.02-0.03$ $\mathrm{L} /(\mathrm{m} . \mathrm{s})$ and the permeability coefficient is $0.02-0.05 \mathrm{~m} / \mathrm{d}$ of clastic rocks pore and fissure aquifer with the thickness of about $100 \mathrm{~m}$, it belongs to the type of weak watery property in Cretaceous system strata. Red sandstone and glutenite are the main lithology of the pore and fracture confined aquifer. The Quaternary system aquifer and Cretaceous system aquifer have some hydraulic connection because of the lack of water-resisting layer.

\section{(3) Jurassic system aquifer}

Jurassic system strata with the thickness of about $127 \mathrm{~m}$ are composed of mudstone, sandy mudstone and fine sandstone. The unit flow rate of water-bearing strata is $0.0016 \sim 0.0045 \mathrm{~L} /(\mathrm{m} . \mathrm{s})$ and the permeability coefficient is $0.0046 \sim 0.013 \mathrm{~m} / \mathrm{d}$ of pore and fissure aquifer, so it has weak watery property in Jurassic system strata. The water permeability and conductivity performance are also weak. So the Jurassic system aquifer has bad hydraulic connection with upper aquifers. 


\section{The effect on river under large height mining}

\subsection{Physical-mechanical properties of rocks}

The overlying strata of 2-2 coal seam are composed of sandstone, glutenite, mudstone, sandy mudstone and fine sandstone. According to the geology supplement exploration, the test results of physical-mechanical properties for overlying rock are shown in Table 1 . The average uniaxial compressive strength of sandstone is $25.9 \mathrm{MPa}$ and the softening coefficient is 0.77 . The average uniaxial compressive strength of siltstone is 14.19 $\mathrm{MPa}$ and the softening coefficient is 0.60 . The average uniaxial compressive strength of sandy mudstone is 30.24 $\mathrm{MPa}$ and the softening coefficient is 0.33 . The average uniaxial compressive strength of mudstone is $25.17 \mathrm{MPa}$ and the softening coefficient is 0.28 .

Table 1. Test results of physical-mechanical properties for overlying rock

\begin{tabular}{|c|c|c|c|c|}
\hline $\begin{array}{c}\text { Sample } \\
\text { No. }\end{array}$ & Depth (m) & Lithology & $\begin{array}{c}\text { Uniaxial } \\
\text { compressive } \\
\text { strength } \\
\text { (MPa) }\end{array}$ & $\begin{array}{l}\text { Softening } \\
\text { coefficien }\end{array}$ \\
\hline 1 & $213.16-225.03$ & Siltstone & 23.84 & 0.27 \\
\hline 2 & $226.12-230.66$ & $\begin{array}{c}\text { Sandy } \\
\text { mudstone }\end{array}$ & 20.84 & 0.22 \\
\hline 3 & $231.10-232.96$ & Siltstone & 34.73 & 0.35 \\
\hline 4 & $233.75-236.81$ & Mudstone & 13.89 & 0.29 \\
\hline 5 & $237.01-241.36$ & $\begin{array}{c}\text { Fine } \\
\text { sandstone }\end{array}$ & 19.26 & 0.74 \\
\hline 6 & $221.34-229.27$ & Siltstone & 3.97 & 0.73 \\
\hline 7 & $230.52-239.29$ & $\begin{array}{c}\text { Fine } \\
\text { sandstone }\end{array}$ & 5.18 & 0.53 \\
\hline 8 & $244.23-247.39$ & Siltstone & 14.77 & 0.81 \\
\hline 9 & $247.58-253.40$ & Mudstone & 36.45 & 0.27 \\
\hline 10 & $217.79-225.12$ & $\begin{array}{c}\text { Sandy } \\
\text { mudstone }\end{array}$ & 35.49 & 0.21 \\
\hline 11 & $227.15-230.16$ & $\begin{array}{c}\text { Fine } \\
\text { sandstone }\end{array}$ & 19.10 & 0.89 \\
\hline 12 & $231.30-234.22$ & $\begin{array}{c}\text { Sandy } \\
\text { mudstone }\end{array}$ & 46.58 & 0.23 \\
\hline 13 & $241.80-243.12$ & $\begin{array}{c}\text { Fine } \\
\text { sandstone }\end{array}$ & 29.39 & 0.70 \\
\hline 14 & $243.75-244.60$ & $\begin{array}{c}\text { Sandy } \\
\text { mudstone }\end{array}$ & 33.13 & 0.34 \\
\hline 15 & $245.25-246.25$ & Gritstone & 56.57 & 0.97 \\
\hline 16 & $247.09-247.59$ & $\begin{array}{c}\text { Sandy } \\
\text { mudstone }\end{array}$ & 15.16 & 0.55 \\
\hline Average & & & 25.52 & 0.48 \\
\hline
\end{tabular}

The average uniaxial compressive strength of overlying rock is $25.52 \mathrm{MPa}$ and most of overlying rock is less than $30 \mathrm{MPa}$, the strength of overlying rock is relatively low. The average softening coefficient is 0.48 and most samples are less than 0.75 , so the rocks are easily softened. Based on the partitioning method of rock strength ${ }^{[11]}$ (as shown in Table 2), the overlying rocks of 2-2 coal seam belong to medium hard type.

Table 2. Partitioning method of overlying rock

\begin{tabular}{|c|c|c|}
\hline Types & $\begin{array}{c}\text { Uniaxial } \\
\text { compressive } \\
\text { strength } \\
\text { (MPa) }\end{array}$ & Main rocks \\
\hline Hard & $40 \sim 80$ & $\begin{array}{c}\text { quartz sandstone, } \\
\text { limestone, sandy shale, } \\
\text { conglomerate }\end{array}$ \\
\hline $\begin{array}{c}\text { Medium } \\
\text { hard }\end{array}$ & $20 \sim 40$ & $\begin{array}{c}\text { sandstone, argillaceous } \\
\text { limestone, sandy shale, } \\
\text { shale }\end{array}$ \\
\hline Weak & $10 \sim 20$ & $\begin{array}{c}\text { Mudstone, argillaceous } \\
\text { sandstone }\end{array}$ \\
\hline $\begin{array}{c}\text { Very } \\
\text { weak }\end{array}$ & $<10$ & $\begin{array}{c}\text { bauxite, weathered } \\
\text { mudstone, clay, sandy clay }\end{array}$ \\
\hline
\end{tabular}

\subsection{Impact assessment to the river after mining}

From 1950s to now, many research about the mining method under water body. For the research of caving zone and fissure zone (as shown in Fig.4), field observation is the main method coupled with model test, numerical analysis, and physical simulation and so on. Based on a large number of in si-tu observations, empirical formulas for the heights of caving zone and fissure zone are summarized. In the 21 st century, with the development of large mining height method and computer technology, the growth characteristics of caving zone and fissure zone have been known specifically. The empirical formulas of caving zone and fissure zone for the large mining heights have also been formed (as shown in Table 3) and scientifically instructed the safety mining under water bodies ${ }^{[12]}$.

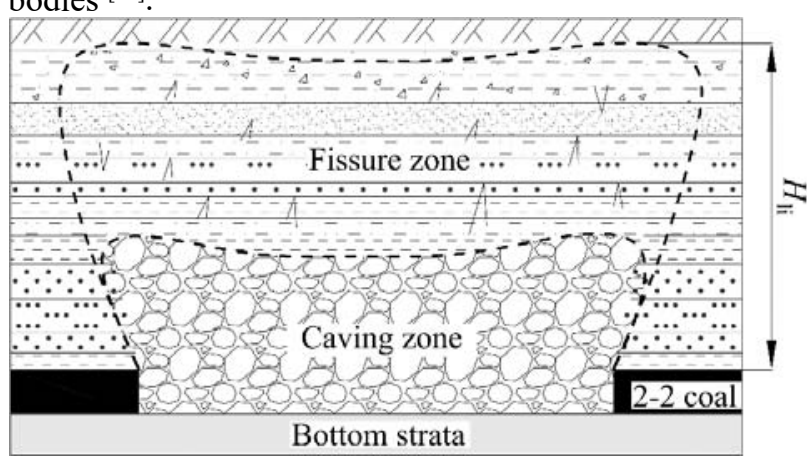

Fig.4. Characteristics of overburden failure

Table 3. Empirical formulas of "two zones"

\begin{tabular}{|c|c|c|}
\hline \multicolumn{2}{|c|}{$\begin{array}{c}\text { Overlying rock } \\
\text { types }\end{array}$} & \multirow{2}{*}{$\begin{array}{c}\text { Empirical formulas }(\mathbf{m}) \\
H_{k}=7 M+5\end{array}$} \\
\hline \multirow{3}{*}{$\begin{array}{l}\text { Cavin } \\
\text { g zone } \\
\text { height }\end{array}$} & Hard & \\
\hline & $\begin{array}{l}\text { Mediu } \\
\mathrm{m} \text { hard }\end{array}$ & $H_{k}=6 M+5$ \\
\hline & Weak & $H_{k}=5 M+5$ \\
\hline
\end{tabular}




\begin{tabular}{|l|c|l|l|}
\hline \multirow{2}{*}{$\begin{array}{l}\text { Fissur } \\
\text { e zone } \\
\text { height }\end{array}$} & Hard & $H_{\mathrm{li}}=\frac{100 M}{0.15 M+3.12} \pm 11.1$ & $H_{l i}=30 M+10$ \\
\cline { 2 - 4 } & $\begin{array}{l}\text { Mediu } \\
\mathrm{m} \text { hard }\end{array}$ & $H_{\mathrm{li}}=\frac{100 M}{0.23 M+6.10} \pm 10.42$ & $H_{l i}=20 M+10$ \\
\cline { 2 - 4 } & Weak & $H_{\mathrm{li}}=\frac{100 M}{0.31 M+8.81} \pm 8.21$ & $H_{l i}=10 M+10$ \\
\hline
\end{tabular}

Where $\mathrm{M}$ is mining height, $\mathrm{m}$.

According to the data of 11 boreholes in the research area, the thickness of 2-2 coal seam is from $3.47 \mathrm{~m}-4.12$ $\mathrm{m}$, with average thickness of $3.84 \mathrm{~m}$. Based on above analysis, the overlying rocks belong to medium hard type. The fissure zone heights of different boreholes are shown in Table 4. The maximum height of fissure zone is 92.40 $\mathrm{m}$ in borehole $\mathrm{H} 5$.

Through above analysis, Quaternary system aquifer has an intimate hydraulic connection with the Youfang River. The average depth of 2-2 coal seam is $251.46 \mathrm{~m}$ and the minimum depth is $211.49 \mathrm{~m}$. The maximum fissure zone height only is $92.40 \mathrm{~m}$, which can't reach the Quaternary system aquifer. That is, Youfang River won't be affected through the large height mining in Wotugou coal mine.

Table 4. Fissure zone height of research area

\begin{tabular}{|c|c|c|c|c|}
\hline $\begin{array}{c}\text { Borehole } \\
\text { S }\end{array}$ & $\begin{array}{c}\text { Coal } \\
\text { depth } \\
\text { (m) }\end{array}$ & $\begin{array}{c}\text { Thickness } \\
\text { of coal (m) }\end{array}$ & $\begin{array}{c}\text { Fissure zone } \\
\text { height 1 (m) }\end{array}$ & $\begin{array}{c}\text { Fissure } \\
\text { zone height } \\
\mathbf{2}(\mathbf{m})\end{array}$ \\
\hline H3 & 244.63 & 3.96 & 66.90 & 89.20 \\
\hline H4 & 230.35 & 3.66 & 63.14 & 83.20 \\
\hline H5 & 211.49 & 4.12 & 68.88 & 92.40 \\
\hline H6 & 271.47 & 4.11 & 68.76 & 92.20 \\
\hline H9 & 234.38 & 3.95 & 66.78 & 89.00 \\
\hline H10 & 232.64 & 3.52 & 61.36 & 80.40 \\
\hline H11 & 265.45 & 4.04 & 67.89 & 90.80 \\
\hline H12 & 262.52 & 3.6 & 62.38 & 82.00 \\
\hline H13 & 291.44 & 3.47 & 60.72 & 79.40 \\
\hline H14 & 224.17 & 3.73 & 64.03 & 84.60 \\
\hline H15 & 260.16 & 4.08 & 68.39 & 91.60 \\
\hline Average & $\mathbf{2 5 1 . 4 6}$ & $\mathbf{3 . 8 4}$ & 65.41 & 86.80 \\
\hline
\end{tabular}

\section{The effect on earth dam under large height mining}

\subsection{Impact assessment to the river after mining}

For the prediction of surface movement and deformation, many experts from domestic and overseas have put forward different methods. After systematic research and practice for more than 40 years, the law of surface movement and deformation have been mastered. Probability integral method, negative exponential method, Weibull function method and typical curve method are usually used to predict surface movement and deformation in China ${ }^{[13]}$. Parameters are easily determined and practicability is high for the probability integral method, so it is used widely. For that reason, probability integral method was used to predict the deformation of earth dam under large height mining.

Subsidence and horizontal deformation formulas of every point and every direction in the surface subsidence trough are as follows:

(1) Surface subsidence computation

$$
W(x, y)=W_{\text {cm }} \iint_{D} \frac{1}{r^{2}} e^{-\pi \frac{(\eta-x)^{2}+(\varepsilon-y)^{2}}{r^{2}}} d \eta d \xi
$$

(2) Horizontal deformation computation

$$
\begin{aligned}
& \varepsilon_{x}(x, y)=U_{\mathrm{cm}} \iint_{D} \frac{2 \pi}{r^{3}}\left(\frac{2 \pi(\eta-x)^{2}}{r^{2}}-1\right) e^{-\pi \frac{(\eta-x)^{2}+(\xi-y)^{2}}{r^{2}}} d \eta d \xi \\
& \xi_{y}(x, y)=\frac{\partial U_{y}(x, y)}{\partial y}=U_{\mathrm{cm}} \iint_{D} \frac{2 \pi}{r^{3}}\left(\frac{2 \pi(\xi-y)^{2}}{r^{2}}-1\right) \\
& \cdot e^{-\pi \frac{(\eta-x)^{2}+(\varepsilon-y)^{2}}{r^{2}}} d \eta d \xi+i_{y}(x, y) \operatorname{ctg} \theta
\end{aligned}
$$

Where $r$ is major influence radius, is related to mining depth and the main influence angle, $\mathrm{m} ; D$ is the mining area; $x, y$ is relative coordinates of point, $\mathrm{m} ; W_{\mathrm{cm}}$ is the maximum subsidence value, $\mathrm{mm} ; U_{\mathrm{cm}}$ is the maximum horizontal movement value, $\mathrm{mm}$.

The ranges of surface movement computation parameters for different overlying strata in different areas have been summarized in China. The applicability of these parameters is very high because of the long-term monitoring. Wotugou coal mine near to Bulianta coal mine (as shown in Fig. 1) has the similar geological condition, mining method and mining scale, so the parameters of Bulianta coal mine can be used to compute the earth dam deformation. Deformation contour line can be drawn after computation when the parameters and mining information are imported the probabilistic integration method software. The relevant parameters are shown in Table 5.

Table 5. Parameters for surface deformation prediction

\begin{tabular}{|c|c|c|c|}
\hline $\begin{array}{c}\text { Subsidence } \\
\text { coefficient }\end{array}$ & $\begin{array}{c}\text { Horizontal } \\
\text { movement } \\
\text { coefficient }\end{array}$ & $\begin{array}{c}\text { Propagation } \\
\text { angle }\left(^{\circ}\right)\end{array}$ & $\begin{array}{c}\text { Tangent of } \\
\text { main } \\
\text { influencing } \\
\text { Angle }\end{array}$ \\
\hline 0.55 & 0.20 & 89 & 2.2 \\
\hline
\end{tabular}

\subsection{Earth dam deformation computation}

The relevant working faces for the earth dam deformation computation are shown in Table 6 . Subsidence value was computed through working faces mined one by one. Subsidence contour maps for 3 working faces (12201, 12202 and 12203) and 6 working faces (12201 to 12206) mined are shown in Fig. 5 and Fig. 6 respectively. Subsidence of $10 \mathrm{~mm}$ was taken as the boundary of influence range caused by mining. The surface subsidence increased with the expansion of mining range. The maximum surface subsidence reached $1.7 \mathrm{~m}$ after 3 working faces mined and the maximum value tended to be 
stable after 6 working faces mined. The earth dam didn't be affected because of the uniform subsidence.

Table 6. Working faces in the research area

\begin{tabular}{|c|c|c|c|}
\hline $\begin{array}{c}\text { Working } \\
\text { faces }\end{array}$ & $\begin{array}{c}\text { Length } \\
(\mathbf{m})\end{array}$ & Width $(\mathbf{m})$ & $\begin{array}{c}\text { Mining } \\
\text { thickness } \\
(\mathbf{m})\end{array}$ \\
\hline 12201 & 1700 & 300 & 3.84 \\
\hline 12202 & 1700 & 300 & 3.84 \\
\hline 12203 & 1400 & 300 & 3.84 \\
\hline 12204 & 1700 & 300 & 3.84 \\
\hline 12205 & 1435 & 300 & 3.84 \\
\hline 12206 & 1435 & 300 & 3.84 \\
\hline
\end{tabular}

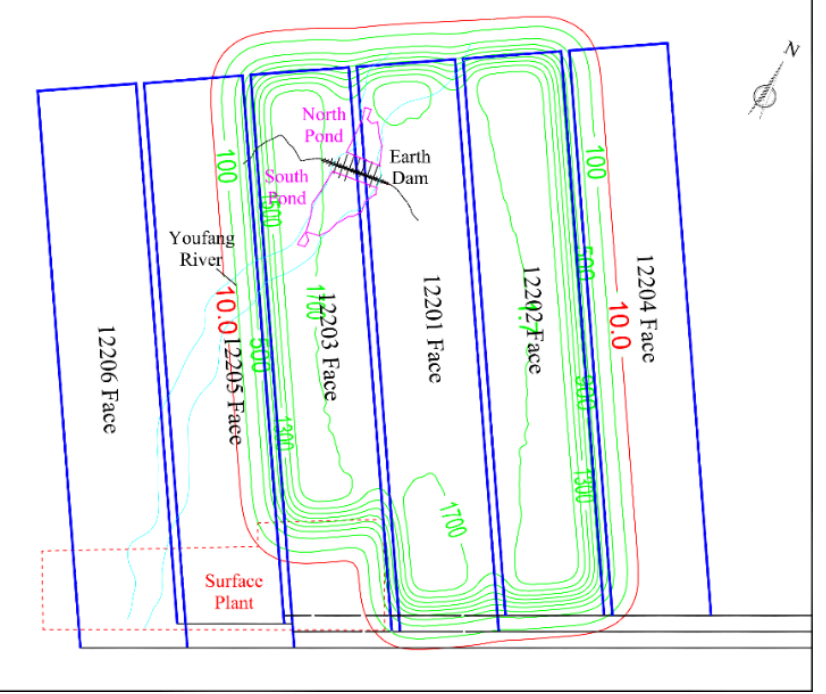

Fig. 5. Subsidence contour map for 3 working faces mined

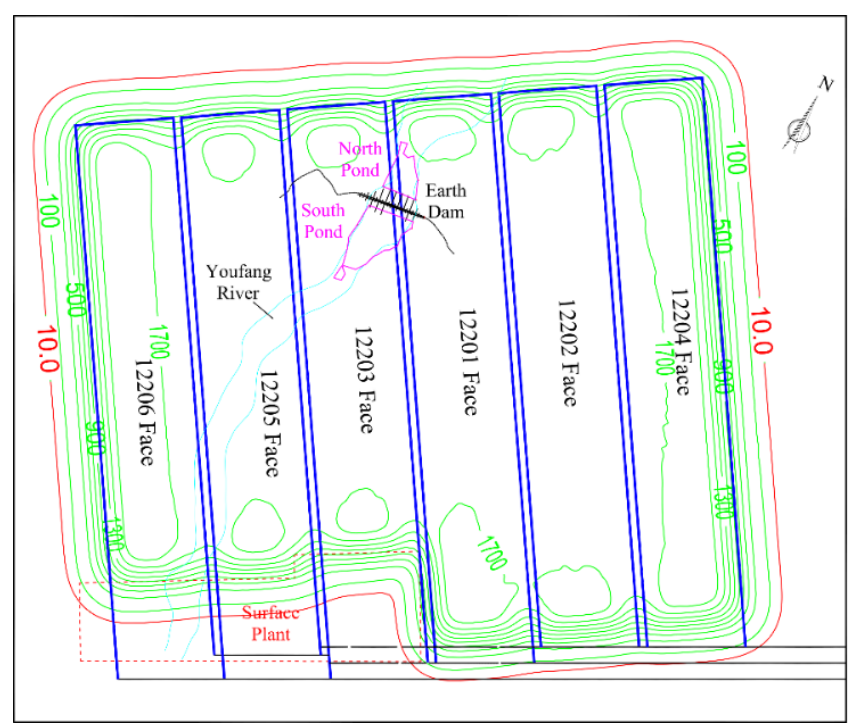

Fig. 6. Subsidence contour map for 6 working faces mined

Horizontal deformation contour maps for 3 working faces $(12201,12202$ and 12203) and 6 working faces (12201 to 12206) mined are shown in Fig. 7 and Fig. 8 respectively. Horizontal deformation increased with the working faces mined one by one. The maximum horizontal deformation in the strike and incline directions reached $4.0 \mathrm{~mm} / \mathrm{m}$ after 3 working faces mined and the maximum value tended to be stable after 6 working faces mined.

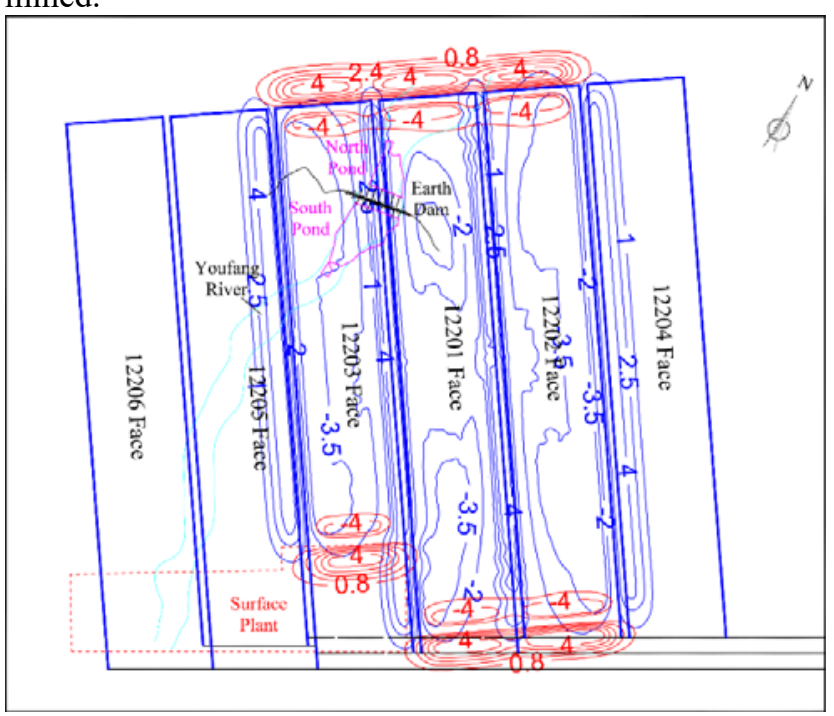

Fig. 7. Horizontal deformation contour map for 3 working faces mined

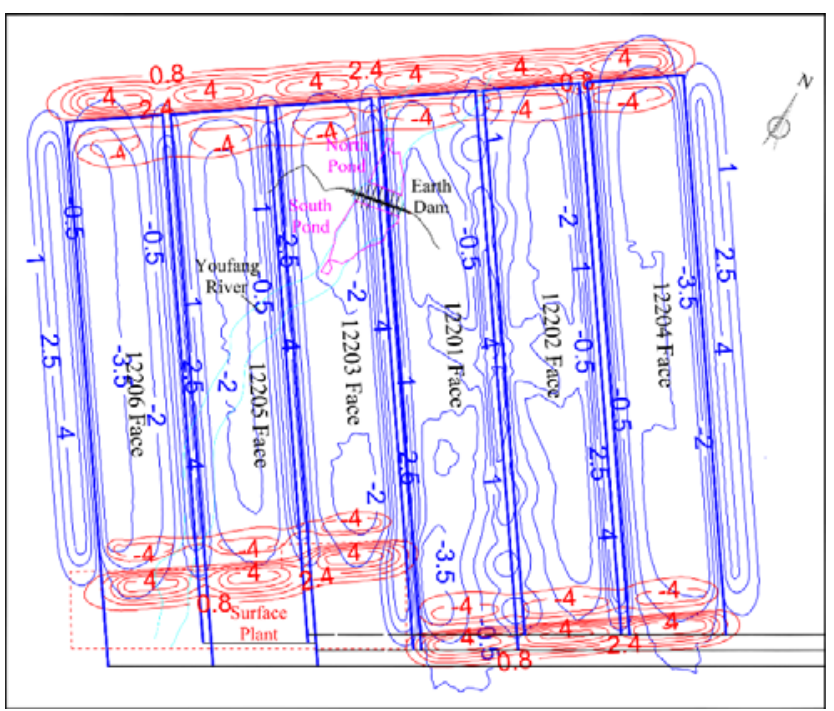

Fig. 8. Horizontal deformation contour map for 6 working faces mined

According to 'The coal pillar design and mining standard for construction, water body, railway, main shaft and roadway', earth dam reached the allowable maximum value $4.0 \mathrm{~mm} / \mathrm{m}$. To a certain extent, the earth dam was affected by the underground mining, so some safety measures needed to be done as follows:

(1) The height and width of the dam should be increased, and reinforcement measure should be used because of the earth dam subsidence;

(2) The slope of dam made a difference caused by the incline deformation, then skid-resistance decreased, the measures of decreasing the slope and increasing the width should be used to improve the anti-sliding ability.

(3) Fractures were generated in the dam because of the horizontal deformation. The fractures should be governed through backfill and grout methods.

(4) Earth dam should be monitored and maintained during mining, especially in the rainy season. 


\section{Conclusions}

(1) Quaternary system aquifer belongs to the type of weak to strong watery property and has an intimate hydraulic connection with the Youfang River through analyzing the hydrogeological condition.

(2) The overlying strata of 2-2 coal seam are composed of sandstone, glutenite, mudstone, sandy mudstone and fine sandstone and the average uniaxial compressive strength of overlying rock is $25.52 \mathrm{MPa}$ after analyzing the geological condition. The overlying rocks of 2-2 coal seam belong to medium hard type and the maximum height of fissure zone is $92.40 \mathrm{~m}$. There is no effect on Youfang River after large height mining under the depth of $251.46 \mathrm{~m}$.

(3) Probability integral method was used to predict the deformation of earth dam under large height mining. The maximum surface subsidence reached $1.7 \mathrm{~m}$ and the horizontal deformation reached the allowable maximum value $4.0 \mathrm{~mm} / \mathrm{m}$, there would be some effect on the earth dam, so some safety measures are put forward and needed to be done.

\section{Acknowledgment}

Foundation projects: National Natural Science Foundation Project (51804162).

\section{References}

1. J.H. Li, Y.C. Xu, J.P. Dong, W.Y. Guo, X.C. Cao. JCCS, 41, 984-991 (2016)

2. C. Niu, L.Q. Shi, L.L. Xiao, P.H. Zhai, S.L. Wu, Y.H. Zhao. S CM, 46, 208-211 (2015)

3. T.Q. Liu. CST, 2, 14-19 (1984)

4. T.Q. Liu. CST, 10, 18-24 (1986)

5. Y.S. Zhou, X.K Wen. CST, 26, 53-55 (1998)

6. Y.H. Kang. CST, 26, 35-38 (1998)

7. J. F, H. J. Xu, Z.G. Cao. CST, 44, 67-73 (2016)

8. Y.M. Li, Y.H. Kang, C.C. Gao. CST, 31, 1-5, (2003)

9. National Coal Industrial Bureau. Rules for coalmining relating to building, water body, railway and main tunnel. (2017)

10. Y.C. Xu, S.Q. Liu. CST, 39, 1-4 (2011)

11. J.H. Li, Y.C. Xu, W.Z. Gu. IJMME, 6, 276-293 (2015)

12. Y.C. Xu, S.Q. Liu, Z.X. Liu. JMSE, 30, 506-511 (2013)

13. J.H. Li, H.J. Li, Z.C. Li. JMSCE, 2, 013538 (2020) 